\title{
The Mechanism of the Effects of Experiential Marketing on Urban Consumers' Well-Being
}

\author{
Hongshen Liu $(\mathbb{D}$, Yuying Fu $(\mathbb{D}$, and Hao He $\mathbb{D}$ \\ School of Economics and Management, Changsha University of Science and Technology, Changsha 410114, China \\ Correspondence should be addressed to Hao He; mailhehao@163.com
}

Received 19 August 2020; Revised 18 September 2020; Accepted 26 September 2020; Published 15 October 2020

Academic Editor: Jun Yang

Copyright ( 92020 Hongshen Liu et al. This is an open access article distributed under the Creative Commons Attribution License, which permits unrestricted use, distribution, and reproduction in any medium, provided the original work is properly cited.

\begin{abstract}
Knowing how to improve urban consumers' well-being is of great importance for sustainable urban development and has become a research hotspot in the field of service marketing, which is evolving from functionality-focused view into experience-focused view. This study explored the mechanism and boundary conditions of experiential marketing on urban consumers' well-being with a survey data collected from 256 consumers in the catering service industry in China. The results showed that experiential marketing had a significant positive impact on consumer well-being, experiential value played a partial mediation role between experiential marketing and consumer well-being, value proposition engagement moderated the relationship between experiential value and consumer well-being, and value proposition engagement moderated the mediation role of experiential value between experiential marketing and consumer well-being. This study complements the literature of transformative service by revealing a complex mechanism relating to the effects of experiential marketing on urban consumers' well-being and provides theoretical guidance for service enterprises to improve their offerings.
\end{abstract}

\section{Introduction}

In 2018, the service industry in China accounted for 52.16\% of its GDP. Consumers are exposed to services provided by supermarkets, banks, hotels, and telecommunication institutions almost every day. However, the traditional service research mainly focuses on consumer satisfaction, loyalty, repurchase intention, and word-of-mouth communication as the outcome of services [1], thus ignoring the question of how the quality of consumer life, such as consumer wellbeing, is affected by services, [2,3]. Consumer well-being refers to consumer perception of the positive contribution of products or services in improving the quality of life [4] and has become an important element ensuring sustainable urban development. In recent years, how to improve consumer well-being has attracted amounts of attention of service researchers and practitioners $[2,5]$. As a new research paradigm in the field of service, transformative service research (TSR), which focuses on how to create tremendous improvements in the well-being of consumers at the individual, community, and even global levels [3], has integrated consumer and service research and advanced towards the relationship between service and consumer well-being greatly [5].

According to the TSR entities and outcomes framework [3], the service entities that affect consumer well-being include service employees, service processes, offerings, organizations, and industrial sectors. Anderson et al. sampled three service sectors of financial service, healthcare services, and social services and discussed how they affected consumer well-being [3]. In addition, by reviewing the literature in China and abroad, it is found that the current research on transformative service research mainly focuses on three aspects: first, to explore the impact of service employees on consumer well-being, such as the interaction between service employees and customers [6] and technical quality and functional quality of service employees [7]; second, to explore the impact of service offerings on consumer wellbeing, such as refurbishing service [8], diversified service choices [9], and service attributes [10]; and third, to explore the impact of service organizations on consumer well-being, such as organizational socialization and organizational 
support [2, 5]. Thus, the existing literature has not yet addressed the impact of service processes on consumer wellbeing in service entities.

With rapid economic development, consumers are trying to get a special and unforgettable experience from services, rather than purchasing a high-quality service alone [11]. Pine and Gilmore conceptualized this phenomenon as the experience economy [12]. As a new way of thinking about and new mode of marketing in the era of experience economy, experiential marketing is an interactive process between consumers and companies that meets consumer experience needs in an interactive way [13]. Thus, experiential marketing can well explain the service process in service entities. In addition, as an extension of the service economy, well-being is the essence of experience economy [14]. Therefore, this study tries to fill the gap of previous studies and explore the impact of the service process, i.e., experiential marketing on consumer wellbeing, and further enrich and improve TSR. Specifically, this study attempts to provide empirical evidence for the following questions: first, whether consumer experiential value plays a mediating role between experiential marketing and consumer well-being, and second, whether value proposition engagement plays a moderating role in the mediating role of experiential value. To answer the above questions, this study constructs a theoretical model to explain the relationship between experiential marketing, experiential value, value proposition engagement, and consumer well-being and provides empirical evidence to verify them. It is hoped that the findings from this study will help guide practitioners to improve their services quality and constantly enhance consumer well-being.

\section{Literature Review and Hypotheses}

2.1. Experiential Marketing and Consumer Well-Being. Experiential marketing was first proposed by Schmitt [13], who redefined and designed the thinking mode of marketing on the basis of consumer senses, feelings, thinking, action, and relation. The key to experiential marketing is to satisfy consumers' experience needs. Experiential marketing no longer regards consumers as being completely rational but as being both rational and perceptual when consuming products or services. Currently, experiential marketing has attracted increasing attention from enterprises and has gradually become the core mode of global marketing. In academia, research on experiential marketing is focused on the outcome variables, such as customer purchase intention [15], customer satisfaction [16], customer loyalty [17], customer word-of-mouth communication [17], and experience value [18]. It can be seen that scholars are still guided by the performance of service organizations, neglecting the quality of life of consumers themselves, and have not yet explored experiential marketing as a new marketing model of how to affect consumer well-being. Therefore, this study attempts to explore how experiential marketing affects consumer well-being.

Since the 1980s, based on bottom-up spillover theory and Maslow's hierarchical theory of needs, consumer wellbeing has been used to analyse how marketing activities affect consumer quality of life. Consumer well-being refers to the overall satisfaction evaluation and positive/negative emotional response of consumers to their consumption activities [9]. Consumer well-being is a continuous feeling of laughter and tears, joy and pain, and satisfaction and dissatisfaction [19]. Of course, this feeling is mainly subjective psychological reflection and is only related to the field of consumer life [9]. Thus, consumer well-being mainly focuses on individual subjective evaluation and emotional reflection of consumption activities.

At present, most of the research on consumer well-being is based on the macromarketing perspective. The previous research mainly discusses consumer well-being at different stages of acquisition, preparation, possession, consumption, maintenance, and disposal in consumer activities [20, 21], but there is little existing research on the micromarketing perspective. Consumer well-being from a micromarketing perspective should be based on a product, an experience, or a specific event. Therefore, based on the micromarketing perspective, the current study will specifically explore how experiential marketing affects consumer well-being, expose the psychological mechanism of consumer well-being, and construct a theoretical model and provide some empirical evidence for it.

The core of experiential marketing is to create different forms of experience for consumers so that consumers can undergo a good of experience, which, in the era of an experience economy, cannot be realized by traditional marketing [13]. In fact, experience can bring happiness to people more than material wealth [22]. Similarly, positive experiential purchasing can bring lasting happiness to consumers more than positive material purchasing [23]. Hwang and Lee surveyed 323 elderly people over the age of 65 years and found that when these elderly tourists had a good experience through travel, they were more likely to feel a high level of well-being [14]. According to the research of Hirschman and Holbrook [24], experience has important emotional significance. Thus, positive consumption experience often transforms into inner psychological well-being, which brings consumer well-being. In the era of experiential marketing, the focus of marketing will shift from product performance to entertainment experience [25], so as to better enhance consumer wellbeing. In addition, an experience economy has a positive impact on well-being, so experiential marketing, as an important marketing mode in the experience economy era, should be able to positively affect consumer well-being [14]. Based on the above inferences, this study attempts to propose the following hypothesis.

Hypothesis 1. Experiential marketing is positively related to consumer well-being.

2.2. Experiential Marketing, Experiential Value, and Consumer Well-Being. Based on rational consumption value, Holbrook and Hirschman put forward a new concept of consumption experience and suggested that the experiential value is generated in the process of consumption experience, 
such as hedonic value, symbolic value, and aesthetic value [26]. Experiential value is interactive, relative, and preferential experience [27]. Mathwick, Malhotra, and Rigdon argued that experiential value refers to the degree of relative preference for product attitudes and consumption performance caused by interaction in the process of consumption to help consumers achieve consumption goals [28].

Based on the traditional classification of experiential value from the dimension of intrinsic and extrinsic benefits, Holbrook added a new classification dimension of customer participation initiative, thus constructing an experiential value model including active value, passive value, intrinsic value, and extrinsic value [29]. Based on Holbrook's research, Mathwick, Malhotra, and Rigdon redefined the structural dimension of experiential value and tested it empirically [28]. Finally, experiential value was classified into four dimensions: aesthetic feeling, interestingness, the rate of return on consumer investment, and the superiority of service, which is widely accepted in academic circles. This study adopted this classification to measure experiential value. In empirical research, more scholars are discussing the outcome variables of experiential value, such as customer satisfaction, customer loyalty, customer citizenship behaviour, brand equity, and purchase behaviour [18], and others are discussing the antecedent variables, such as interpersonal interaction, experiential marketing, and brand crisis. At present, no scholars have explored the mediating role of experiential value between experiential marketing and consumer well-being.

Consumption is no longer a simple purchase decision but an experience. Experiential marketing helps to enhance the experiential value of consumers [13]. Barlow and Maul also pointed out that experiential marketing provides and creates experiential value [6]. The value created by experience is more precious than the pure function and benefit of the product [13]. Successful experience can not only satisfy the external value but also satisfy the inner value [29]. In terms of service superiority in experiential value, when consumers approve of service, they usually have a sense of well-being. Based on the above inferences, this study attempts to propose the following hypothesis.

Hypothesis 2. Experiential value plays a mediating role between experiential marketing and consumer well-being.

\subsection{The Moderation Effect of Value Proposition Engagement.} Value proposition is not only a high generalization of the real needs of consumers but also a prediction and judgement of the value orientation of consumers. Enterprises expect consumers to respond positively to their value proposition, that is, to achieve value proposition engagement [30]. Anderson et al. used resonance to illustrate what value proposition messages could effectively arouse consumers [30]. Grnroos and Voima believed that the resonance originated from the conformity between a long-term psychological state of the information recipient and the information [31]. Resonance can be divided into three dimensions: expectation agreement, value engagement, and spiritual harmony. Value engagement refers to the fact that the message received by the recipient is consistent with its past value orientation. The concept of engagement has been applied in many different research fields, such as the engagement between the organization and the individual [32], the engagement between tools and tasks [33], and the engagement between information and values. The difference between engagement and general concepts is that it refers not to a concept itself but to the consistency of directions between two related concepts. Engagement in this study refers to the consistency of value proposition between consumers and enterprises in direction. Value proposition engagement refers to the coincidence between the value proposition message received by the recipient and the beliefs and values in his long-term memory. That is, consumers identify with and resonate with the value propositions of enterprises [34].

Varey believes that well-being comes from "getting what you want," even if consumers obtain the same experiential value, different degrees of well-being will arise because of different situations of consumer value proposition engagement [35]. Value proposition engagement is a psychological state of consumers on the basis of value proposition cognition, which reflects consumer recognition or resonance to enterprise value proposition [6]. That is, the same experiential value may have totally different meanings for consumers with different degrees of enterprise value proposition engagement. When the degree of value proposition engagement is higher, experiential value has a greater impact on consumer well-being. In contrast, when the degree of value proposition engagement is lower, it weakens the influence of experiential value on consumer well-being. Based on the above inferences, this study attempts to propose the following hypothesis.

Hypothesis 3. Value proposition engagement plays a positive moderating role in the relationship between experiential value and consumer well-being, that is, the higher the degree of value proposition engagement, the greater the impact of experiential value on consumer well-being.

In the above research hypotheses, Hypothesis 2 highlights the mediating role of consumer experiential value between experiential marketing and consumer well-being, while Hypothesis 3 points out that different degrees of value proposition engagement will lead to different effects of experiential value on consumer well-being. On the basis of Hypothesis 2 and 3, this study further proposes a moderated mediation role, that is, value proposition engagement can moderate the mediation mechanism of experiential value between experiential marketing and consumer well-being.

With consumers' experience and their direct participation, experiential marketing creates an unforgettable feeling to maximize the psychological needs of consumers and enhances consumer experiential value. Of course, when the degree of value proposition engagement increases, the influence level of experiential value on consumer well-being is higher. That is, the effect of experiential marketing on consumer well-being becomes obviously enhanced through experiential value. In contrast, when the degree of value 
proposition engagement is lower, it weakens the influence of experiential value on consumer well-being. That is, experiential marketing has obviously weakened its influence on consumer well-being through experiential value. In conclusion, experiential marketing can ultimately enhance consumer well-being by affecting experiential value, but the strength of this role will vary significantly under different value proposition engagement. Based on the above inferences, this study attempts to propose the following hypothesis.

Hypothesis 4. Value proposition engagement can moderate the mediating role of experiential value between experiential marketing and consumer well-being, that is, the higher the degree of value proposition engagement, the stronger the impact of experiential marketing on consumer well-being.

Based on the above hypotheses, this study constructs the following theoretical model (Figure 1).

\section{Methods}

3.1. Sample and Data Collection. This study collected data by means of questionnaires. Four high-end restaurants in China were selected to carry out the survey. In this survey, 400 questionnaires were disseminated and 386 questionnaires were retrieved. After the consistency test, 256 questionnaires were valid, with an effective rate of $64 \%$. Among the 256 valid questionnaires, 58.6\% were completed by women, accounting for a higher proportion. In terms of age distribution, $17.2 \%$ of the questionnaires were completed by individuals 30 years old and under, $44.5 \%$ were $31-40$ years old, $11.7 \%$ were $41-50$ years old, $21.1 \%$ were $51-60$ years old, and $5.5 \%$ were over 61 years old. In terms of education, $7.1 \%$ of the individuals were postgraduates and $32.0 \%$ were undergraduates. Moreover, colleges accounted for $41.0 \%$ and senior high schools/colleges and below accounted for $19.9 \%$. In terms of occupational categories, enterprise staff accounted for $13.3 \%$, enterprise managers accounted for $20.3 \%$, civil servants accounted for $18.8 \%$, science and education personnel accounted for $23.8 \%$, and other occupations accounted for $23.8 \%$. In terms of income, the average monthly income of 4000 yuan accounted for $10.9 \%$, 4001-6000 yuan accounted for 24.2\%, 6001-8000 yuan accounted for $28.6 \%$, and more than 10000 yuan accounted for $12.1 \%$.

3.2. Measures. The measurement scales used in this study were all adapted from the prior research. Experiential marketing used a five-item scale compiled by Schmitt [13]. Experiential value used a four-item scale compiled by Mathwick et al. [28]. Value proposition engagement used a four-item scale compiled by Anderson et al. [30]. Consumer well-being used a three-item scale compiled by Hills Argyle [36]. All constructs were measured using multiple items rated on a 5-point Likert scale ranging from $1=$ strongly disagree to $5=$ strongly agree.

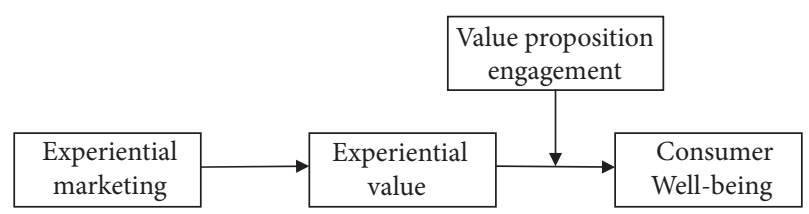

FIGURE 1: Theoretical model.

3.3. Common Method Bias. Common variance means that if variables are filled in by one person, even if there is no theoretical relationship between the variables, they will be related. In this study, each questionnaire was completed by the same person, so there may be common variance. The control methods of common variance are divided into program control and statistical control. First, with regard to program control, this study tried to minimize the participants' guesses about the measurement items and informed the participants that this was an anonymous survey that was being used only for academic research. Second, regarding statistical control, this study drew on the method proposed by Podsakoff et al., placed all measurement items of the four scales together for factor analysis, and evaluated the influence of common variance by the Harman single factor test [37]. The results showed that the variance interpretation rate of the maximum factor without rotation was only $21.88 \%$, which was much lower than $50 \%$. This indicated that there was no single factor in the sample data that could explain most of the variation. It also showed that the problem of common variance in this study was not serious.

\section{Results}

4.1. Reliability and Validity Testing. In terms of reliability, this study mainly tested the internal consistency reliability of the scale and evaluated it by Cronbach's $\alpha$ coefficient. As shown in Table 1, Cronbach's $\alpha$ coefficient of each potential variable was above 0.7 , which indicated that the scale had high reliability and good validity.

In terms of validity, this study mainly tested the convergent and discriminant validity of the scale. To investigate whether there were low-loaded items or multiple-loaded items in the questionnaire, exploratory factor analysis was carried out for all measurement items. The results of the analysis were very satisfactory, and there were no problems mentioned above. Based on exploratory factor analysis, this study used AMOS 18.0 to carry out confirmatory factor analysis. The fit indices were as follows: $\chi^{2} / \mathrm{df}=1.3191, \mathrm{NFI}=0.950, \mathrm{CFI}=0.945$, $\mathrm{GFI}=0.9458, \quad \mathrm{PGFI}=0.641, \quad \mathrm{PNFI}=0.738, \quad$ and $\mathrm{RMSEA}=0.0354$. The above indices showed that the confirmatory factor analysis model had a good fit to the data.

According to Hair et al., the convergent validity of the scale has three evaluation criteria [38]. First, the factor load of each measurement item is better than 0.5. Second, the constructive reliability (CR) of each latent variable is better than 0.7. Third, the average variance extracted (AVE) of each latent variable is better than 0.5 . The data in Table 1 show that all of the above three evaluation criteria had been achieved in this study, which indicates that the scales have high convergent validity. In addition, to test the discriminant validity of the 
TABLE 1: Reliability and convergence validity test.

\begin{tabular}{|c|c|c|}
\hline Latent variables & Measurement items & Factor loading \\
\hline & 1. I am attracted by the decor and design of the restaurant & \\
\hline & 2. The dining atmosphere (lighting, music) in the restaurant & 0.784 \\
\hline Experiential marketing $\alpha=0.889$ & inspires some of my emotions & 0.816 \\
\hline $\mathrm{CR}=0.873$ & 3. The restaurant gives me a fresh perspective on my lifestyle & 0.690 \\
\hline \multirow[t]{3}{*}{$\mathrm{AVE}=0.579$} & 4. The experience of the restaurant will change my actual & 0.751 \\
\hline & behaviour & \multirow[t]{2}{*}{0.757} \\
\hline & 5. I interact and relate with the waiters & \\
\hline \multirow{4}{*}{$\begin{array}{l}\text { Experiential value } \\
\alpha=0.853 \\
\mathrm{CR}=0.850 \\
\mathrm{AVE}=0.587\end{array}$} & \multirow{5}{*}{$\begin{array}{l}\text { 1. When I eat in this restaurant, I think it is worth it } \\
\text { 2. The restaurant provides professional services } \\
\text { 3. Eating in this restaurant makes me temporarily forget the } \\
\text { stresses and worries in real life } \\
\text { 4. The restaurant is clean and tidy } \\
\text { 1. I think the service and dishes provided by the restaurant are in } \\
\text { line with the price }\end{array}$} & 0.756 \\
\hline & & 0.804 \\
\hline & & 0.827 \\
\hline & & 0.669 \\
\hline \multirow{6}{*}{$\begin{array}{l}\text { Value proposition engagement } \\
\alpha=0.879 \mathrm{CR}=0.881, \\
\mathrm{AVE}=0.649\end{array}$} & & \\
\hline & \multirow{2}{*}{$\begin{array}{l}\text { 2. The advertisement of the restaurant affects my emotional } \\
\text { needs }\end{array}$} & 0.828 \\
\hline & & 0.749 \\
\hline & $\begin{array}{l}\text { 3. The decor and design of the restaurant are in line with my } \\
\text { aesthetics }\end{array}$ & $\begin{array}{l}0.786 \\
0.856\end{array}$ \\
\hline & 4. I recognize the value commitment of the restaurant & \\
\hline & 1. It is a pleasure to have dinner in this restaurant & \\
\hline Consumer well-being $\alpha=0.763$ & 2. Compared with the ideal restaurant, this restaurant is satisfying & 0.602 \\
\hline $\mathrm{CR}=0.773$ & to me & 0.709 \\
\hline $\mathrm{AVE}=0.537$ & $\begin{array}{l}\text { 3. Having a meal in this restaurant has provided me with a } \\
\text { pleasant memory }\end{array}$ & 0.864 \\
\hline
\end{tabular}

scales, the principal diagonal in Table 2 lists the arithmetic square roots of $\mathrm{AVE}$ of the corresponding potential variables, while the other numerical values are the absolute values of the correlation coefficients of the corresponding latent variables in the row and column. Obviously, the arithmetic square root of AVE is larger than the absolute value of each correlation coefficient of the row and column, which indicates that the scales have good discriminant validity.

4.2. Hypothesis Testing. To test the mediation effect, this study used the method proposed by Barron and Kenny [39]. The results of the hierarchical regression are shown in Table 3. In Model 1, the regression coefficient of consumer well-being to experiential marketing was significant $(\beta=0.262, p<0.001)$, indicating that experiential marketing had a positive impact on consumer well-being. Therefore, Hypothesis 1 was supported. In Model 2, the regression coefficient of experiential value to experiential marketing was significant $(\beta=0.404, p<0.001)$. In Model 3, the regression coefficient of consumer well-being to experiential value was significant $(\beta=0.280, p<0.001)$. Based on Model 1, when the mediation variable (experiential value) was added in Model 4, the regression of consumer well-being to experiential value was significant $(\beta=0.206, \quad p<0.05)$. Meanwhile, the regression coefficient of consumer well-being to experiential marketing was still significant $(\beta=0.178$, $p<0.05)$. This shows that experiential value played a partial mediating role between experiential marketing and consumer well-being. Therefore, Hypothesis 2 was partially supported.

To further verify the mediating effect of experiential value, the bootstrap method proposed by Preacher et al. was adopted in this study [40]. The results showed that the $95 \%$ confidence interval of the direct effect of experiential marketing on
TABLe 2: Discriminant validity test.

\begin{tabular}{lcccc}
\hline Latent variables & 1 & 2 & 3 & 4 \\
\hline 1. Experiential marketing & 0.761 & & & \\
2. Experiential value & $0.396^{*} *$ & 0.766 & & \\
3. Value proposition & $0.339^{*}$ & $0.494^{* *}$ & 0.806 & \\
engagement & $0.257^{* *}$ & $0.275^{*}$ & $0.302^{* *}$ & 0.733 \\
4. Consumer well-being & 3.695 & 3.713 & 3.657 & 3.553 \\
Mean (M) & 0.712 & 0.737 & 0.760 & 0.654 \\
\hline Standard deviation (SD) &
\end{tabular}

${ }^{*} p<0.05$ and ${ }^{*} p<0.001$. The square root of AVE is shown on the principal diagonal.

consumer well-being was $[0.048,0.281]$, which did not contain 0 . The direct effect was significant, and its coefficient was 0.164 . The $5 \%$ confidence interval of the indirect effect of experiential marketing on consumer well-being through experiential value was $[0.013,0.158]$, which did not contain 0 . The indirect effect was significant, and the coefficient was 0.077 . This showed that $40 \%(0.077 /(0.164+0.077) \times 100 \%)$ of the impact of experiential marketing on consumer well-being was achieved through the mediation variable of experiential value. Therefore, Hypothesis 2 was further supported.

As shown in Table 3, based on Model 5, the interaction item (experiential value $\times$ value proposition engagement) between the mediation variable (experiential value) and the moderation variable (value proposition engagement) was added in Model 6. To prevent multiple collinearity, the mediation variable and the moderation variable in the interaction term were centralized, namely, the values of each variable were multiplied after subtracting their mean values. In Model 6, the interaction term of experiential value and value proposition engagement had a significant positive impact on consumer well-being $(\beta=0.174, p<0.05)$, which 
TABLE 3: Hierarchical regression results of mediation effect and moderation effect.

\begin{tabular}{|c|c|c|c|c|c|c|}
\hline \multirow{2}{*}{ Variables } & \multicolumn{5}{|c|}{ Consumer well-being } & \multirow{2}{*}{$\begin{array}{c}\text { Experiential value } \\
\text { Model } 2\end{array}$} \\
\hline & Model 1 & Model 3 & Model 4 & Model 5 & Model 6 & \\
\hline \multicolumn{7}{|l|}{ Independent variables } \\
\hline Experiential marketing (EM) & $0.262 * *$ & & $0.178^{*}$ & & & $0.404 * *$ \\
\hline \multicolumn{7}{|l|}{ Mediation variables } \\
\hline Experiential value (EV) & & $0.280^{* *}$ & $0.206^{*}$ & $0.175^{*}$ & $0.185^{*}$ & \\
\hline \multicolumn{7}{|l|}{ Moderation variables } \\
\hline Value proposition engagement (VA) & & & & $0.213^{*}$ & $0.260 * *$ & \\
\hline \multicolumn{7}{|l|}{ Interaction term } \\
\hline $\mathrm{EV} \times \mathrm{VA}$ & & & & & $0.174^{*}$ & \\
\hline \multicolumn{7}{|l|}{ Control variables } \\
\hline Gender & -0.118 & -0.080 & -0.094 & -0.074 & -0.062 & $-0.116^{*}$ \\
\hline Age & -0.059 & -0.020 & -0.041 & -0.023 & -0.018 & -0.088 \\
\hline Education & -0.082 & -0.061 & -0.063 & -0.061 & -0.048 & -0.091 \\
\hline Professional & -0.004 & -0.028 & -0.019 & -0.047 & -0.037 & 0.071 \\
\hline Income & $-0.146^{*}$ & $-0.179^{*}$ & $-0.172^{*}$ & $-0.172^{*}$ & $-0.194^{*}$ & $0.123^{*}$ \\
\hline Total $R^{2}$ & 0.119 & 0.127 & 0.153 & 0.161 & 0.188 & 0.192 \\
\hline$F$ & 5.614 & 6.048 & 6.422 & 6.804 & 7.157 & 9.860 \\
\hline
\end{tabular}

Note: ${ }^{*} p<0.05$ and ${ }^{* *} p<0.001$.

indicated that value proposition engagement positively moderated the relationship between experiential value and consumer well-being. Therefore, Hypothesis 3 was supported. To further visually display the moderating role of value proposition engagement, in accordance with the practice of Cohen et al. [41], this study divided the entire sample into two groups according to the level of value proposition engagement. The specific operation methods of grouping were as follows: first, the mean value $(M=3.657)$ and standard deviation $(\sigma=0.760)$ of the value proposition engagement variable were calculated. Then, based on the value of the value proposition engagement variable in the sample, a value proposition engagement variable greater than $4.417(M+\sigma)$ was regarded as a group, and a value less than $2.897(M-\sigma)$ was regarded as another group. Next, with experiential value as the independent variable and consumer well-being as the dependent variable, the data of two groups were analysed by a regression. As shown in Figure 2, the impact of experiential value on consumer well-being was more prominent in the case of high value proposition engagement than in the case of low value proposition engagement.

4.3. Moderated Mediation Effect. To test the moderated mediation effect, the hierarchical regression analysis results of this study are shown in Table 4 .

As shown in Table 4, the regression coefficient of experiential marketing was significant $(\beta=0.275, p<0.05)$ in Model 8. The regression coefficient of the interaction between experiential value and value proposition engagement was significant $(\beta=0.202, p<0.05)$ in Model 9. It showed that value proposition engagement was a moderating variable between experiential marketing and consumer wellbeing through the mediation of experiential value. The second half of the mediation process of "experiential marketing $\longrightarrow$ experiential value $\longrightarrow$ consumer well-being” was moderated by value proposition engagement. Therefore, Hypothesis 4 was supported.

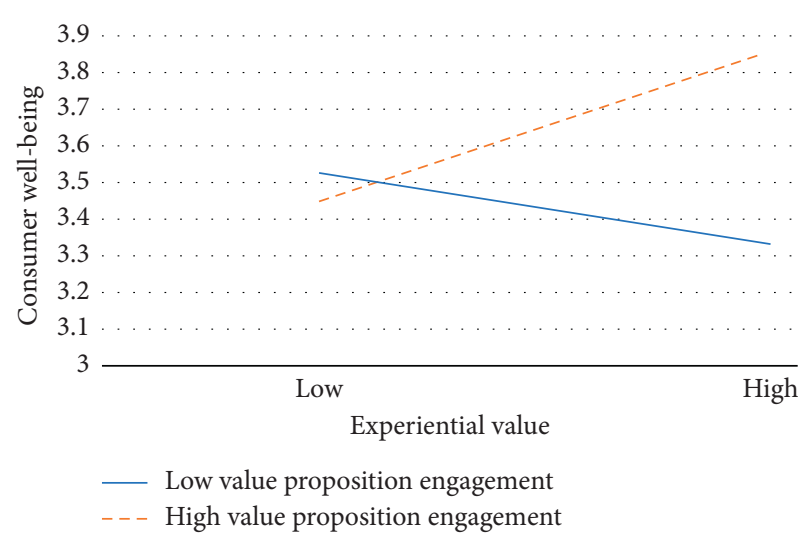

FIgURE 2: The moderation effect of value proposition engagement.

To further test the moderated mediation effect, this study used the PROCESS plug-in developed by Hayes [42] to carry out the bootstrap test proposed by Preacher and Hayes [40]. The sample repetition times were set to 5000 times, and the confidence interval was $95 \%$. The bootstrapping results showed that the moderated mediation effect formed by the moderation variable of value proposition engagement and the mediation variable of experiential value was $[0.007,0.112]$ at the $95 \%$ level, which did not contain 0 , and the coefficient was 0.056 . This fully showed that value proposition engagement moderated the mediating role of experiential value between experiential marketing and consumer well-being. Specifically, when the mean of value proposition engagement was reduced by one standard deviation, the confidence interval of the moderated mediation effect at the 95\% level was [-0.057, $0.102]$, which contained 0 . When the mean of value proposition engagement was added by one standard deviation, the confidence interval was [0.031, 0.186], which did not contain 0 . This showed that the mediating role of consumer experiential value was gradually significant 
TABLE 4: Hierarchical regression results of moderated mediation effect.

\begin{tabular}{|c|c|c|c|c|c|c|}
\hline \multirow{3}{*}{ Variables } & \multirow{2}{*}{\multicolumn{2}{|c|}{$\begin{array}{l}\text { Consumer well-being } \\
\text { Model } 7\end{array}$}} & \multirow{2}{*}{\multicolumn{2}{|c|}{$\begin{array}{c}\text { Experiential value } \\
\text { Model } 8\end{array}$}} & \multirow{2}{*}{\multicolumn{2}{|c|}{$\begin{array}{l}\text { Consumer well-being } \\
\text { Model } 9\end{array}$}} \\
\hline & & & & & & \\
\hline & Coefficient & $T$ & Coefficient & $T$ & Coefficient & $T$ \\
\hline \multicolumn{7}{|l|}{ Independent variables } \\
\hline Experiential marketing (EM) & $0.176^{*}$ & 2.818 & $0.275^{*}$ & 4.893 & 0.097 & 1.494 \\
\hline \multicolumn{7}{|l|}{ Mediation variables } \\
\hline Experiential value (EV) & & & & & $0.165^{*}$ & 2.363 \\
\hline \multicolumn{7}{|l|}{ Moderation variables } \\
\hline Value proposition engagement (VA) & $0.232^{*}$ & 3.699 & $0.396^{*}$ & 7.019 & $0.232 * *$ & 3.348 \\
\hline \multicolumn{7}{|l|}{ Interaction term } \\
\hline $\mathrm{EM} \times \mathrm{VA}$ & -0.055 & -0.915 & 0.074 & 1.375 & $-0.130^{*}$ & -2.089 \\
\hline $\mathrm{EV} \times \mathrm{VA}$ & & & & & $0.202 *$ & 3.124 \\
\hline \multicolumn{7}{|l|}{ Control variables } \\
\hline Gender & -0.103 & -1.706 & -0.069 & -1.277 & -0.086 & -1.445 \\
\hline Age & -0.042 & -0.695 & -0.080 & -1.484 & -0.013 & -0.216 \\
\hline Education & -0.072 & -1.152 & -0.075 & -1.329 & -0.046 & -0.751 \\
\hline Professional & -0.031 & -0.532 & 0.017 & 0.315 & -0.020 & -0.354 \\
\hline Income & $-0.149^{*}$ & -2.382 & 0.109 & 1.933 & $-0.189^{*}$ & -3.029 \\
\hline Total $R^{2}$ & \multicolumn{2}{|c|}{0.169} & \multicolumn{2}{|c|}{0.328} & \multicolumn{2}{|c|}{0.213} \\
\hline$F$ & \multicolumn{2}{|c|}{6.300} & \multicolumn{2}{|c|}{15.103} & \multicolumn{2}{|c|}{6.640} \\
\hline
\end{tabular}

Note: ${ }^{*} p<0.05$ and ${ }^{* *} p<0.001$.

with the enhancement of value proposition engagement. Therefore, Hypothesis 4 was supported again.

\section{Discussion}

5.1. Research Conclusion. In this study, 256 consumers from 4 high-end restaurants in China were selected as the subjects to examine the influence of experiential marketing on consumer well-being. Several findings were obtained:first, experiential marketing had a significant positive impact on consumer wellbeing, and experiential marketing also had a significant positive impact on experiential value. Second, experiential value played a partial mediating role between experiential marketing and consumer well-being. Third, value proposition engagement played a moderating role between experiential value and consumer well-being, that is, the higher the value proposition engagement was, the greater the positive impact of experiential value on consumer well-being. Fourth, value proposition engagement could moderate the indirect effect of experiential marketing on consumer well-being through experiential value, that is, the higher the proposition engagement was, the greater the positive impact of experiential marketing on consumer well-being through experiential value.

5.2. Theoretical Implications. This study enriched the understanding of TSR on consumer well-being by exploring the mechanism of experiential marketing on consumer wellbeing. In traditional service research, previous researchers spent 25 years (1980-2015) focusing on the driving factors of service quality, such as customer satisfaction, customer loyalty, and service recovery. However, these topics were almost constrained to the perspective from management and hardly concerned about consumer well-being [1]. However, TSR regarded consumer well-being as the core element of service marketing. According to the TSR entities and outcomes framework proposed by Anderson et al. [3], among the five service entities affecting consumer wellbeing, no scholar has specifically explored the impact of service process on consumer well-being. In reality, experiential marketing is the process of creating a panoramic experience for consumers. Therefore, by taking experiential marketing as a service process, this study constructed a theoretical model to explain the mechanism of experiential marketing on consumer well-being, which conformed to the essence of TSR and further enriched the theoretical content of TSR.

This study revealed the intrinsic mechanism that the essence of the experience economy was well-being. In the era of the experience economy, the focus of enterprise management has changed from products and services to providing customers with experience [2]. Therefore, the great change confronted by marketing today is the emergence of experiential marketing. This study revealed the intrinsic mechanism of the effect of experiential marketing on consumer well-being, that is, experiential marketing positively affected experiential value, while experiential value positively affected consumer well-being and experiential value played a mediating role between them. The experience economy is a completely new economic formation. Experience marketing, as a representative marketing mode in the era of the experience economy [16], has also become an important source for enterprises to gain competitive advantages. Therefore, to some extent, the conclusion of this study also revealed the intrinsic mechanism that well-being was the essence of the experience economy.

This study also explored the boundary conditions of the relationship between experiential marketing and consumer well-being, thus furthering the understanding on the precedents of consumer well-being. According to Muller et al. [43], mediation variables were mainly for exploring the intrinsic mechanism of relationship formation, while 
moderation variables were for exploring the boundary conditions of its intrinsic mechanism. The results of this study showed that value proposition engagement significantly moderated the relationship between experiential marketing and consumer well-being. This was because when the value proposition engagement was low, the experiential value transmitted by enterprises did not match the value needed by consumers. Therefore, the higher the experiential value, the lower the consumer well-being. Moreover, this study further proved that value proposition engagement moderated the mediating role of experiential value. Therefore, these conclusions well explained the boundary conditions of the functional mechanism between experiential marketing and consumer well-being and deepened our knowledge about the formation of consumer well-being [14].

5.3. Managerial Implications. Our findings indicate that enterprises in service industry need to attach importance to experiential marketing and constantly improve consumer wellbeing. Service economy refers to an economic state in which the proportion of service industry output value in gross domestic product (GDP) exceeds 60\%. Although China's proportion in 2018 was only $52.16 \%$, according to China's economic development trend, it will soon enter the service economy era. In addition, China's economic development is regionally unbalanced, and Shanghai's service industry output value as early as 2012 has exceeded $60 \%$ of the city's GDP and formally entered the service economy era. The experience economy is the extension of the service economy. With the continuous change of economic form, consumer demand is increasingly diversified and refined at a high level. More importantly, well-being is the ultimate goal of life, and the pursuit of well-being is the natural right of human beings. In 2017, KRC Research surveyed 2,100 consumers and 1,050 executives in 21 markets around the world. The survey found that $46 \%$ of consumers would buy more products or services from companies that improved their well-being, so well-being became the primary driver of consumers' purchasing behaviour. At present, most enterprises in China are still pursuing consumer satisfaction, which is not conducive to the long-term development of enterprises and social progress. Therefore, going from satisfaction marketing to well-being marketing is an inevitable trend of social development and human progress, and it is also a practical problem that enterprises need to seriously study and think about. To continuously improve consumer well-being, it is the general trend for enterprises to carry out experiential marketing.

Enterprises should pay attention to consumer experiential value and give full consideration to its mediating role. With intense market competition, modern service enterprises are paying increasing attention to consumer experiential value to meet consumers' different experience needs and personalized experience choices. The results of this study showed that experiential value played a partial mediating role between experiential marketing and consumer well-being. Therefore, this study highlights the importance of enhancing consumer experiential value through experiential marketing to improve consumer well-being. Consumer experiential value is an experience related to consumer preferences. It has interaction and relativity [27]. In experiential marketing, enterprises need to strengthen interaction with consumers, such as product interaction and interpersonal interaction. Through interaction, consumer experiential value can be enhanced, such as functional experiential value, emotional experiential value, and social experiential value [44], to enhance consumer well-being.

Enterprises should keep track of consumer demand dynamics to ensure value proposition engagement with the consumer. The research finds that the impact of experiential value on consumer well-being will be weakened when the value proposition engagement is low. The results showed that when an enterprise provided experiential value that was inconsistent with consumer value proposition, the effect was counterproductive. Therefore, enterprises need to strengthen communication with consumers, understand the changing needs of consumers in a timely fashion, and publicize their value propositions through official websites, forums, and selfmedia platforms so that the value propositions are consistent with the beliefs and values in the consumers' long-term memory. That is, the elaboration of value propositions by enterprises needs to be recognized or resonated with consumers [30] and be kept in line with consumer value.

5.4. Limitations and Future Research Directions. Although this study has certain theoretical value and practical significance for service enterprises to enhance consumer well-being, it still has some limitations. First, because this study only collected data in the high-end catering industry, the results may not be necessarily representative. To obtain higher external validity, future studies could continue to examine the influence of experiential marketing on consumer well-being in other service scenarios. Second, in the findings of this study, experiential value only played a partial mediating role, which indicated that there might be other mediation mechanisms. In future research, we can break through the value theory framework and further explore the mediation mechanism between experiential marketing and consumer well-being, such as through consumer emotion and consumer identity. Third, this study only examined the boundary effect of value proposition engagement, but whether there are other boundary conditions has not yet been discussed. Therefore, in the future, we may explore other boundary conditions of the impact of experiential marketing on consumer well-being.

\section{Data Availability}

The primary data used to support the findings of this study are available from the author upon request.

\section{Conflicts of Interest}

There are no conflicts of interest among authors.

\section{Acknowledgments}

This research was supported by the Scientific Research Fund of Hunan Provincial Education Department of China (Grant 
no. 18A218) and the Natural Science Foundation of Hunan Province (Grant no. 2020JJ4628).

\section{References}

[1] M. S. Rosenbaum, "Transformative service research: focus on well-being," The Service Industries Journal, vol. 35, no. 7-8, pp. 363-367, 2015.

[2] C. N. Azzari and S. M. Baker, "Ten lessons for qualitative transformative service researchers," Journal of Services Marketing, vol. 34, no. 1, pp. 100-110, 2020.

[3] L. Anderson, A. L. Ostrom, C. Corus et al., "Transformative service research: an agenda for the future," Journal of Business Research, vol. 66, no. 8, pp. 1203-1210, 2013.

[4] S. Grzeskowiak and M. J. Sirgy, "Consumer well-being (CWB): the effects of self-image congruence, brand-community belongingness, brand loyalty, and consumption regency," Applied Research Quality Life, vol. 2, pp. 298-304, 2007.

[5] C. Tang, L. Guo, and M. Gopinath, "A social-cognitive model of consumer well-being," Journal of Service Research, vol. 19, no. 3, pp. 307-321, 2016.

[6] A. L. Ostrom, D. Mathras, and L. Anderson, "Transformative service research: an emerging subfield focused on service and well-being," in Handbook of Service Marketing ResearchElgar Publishing, Cheltenham, UK, 2014.

[7] A. D. Keyser and B. Lariviere, "How technical and functional service quality drive consumer happiness: moderating influences of channel usage," Journal of Service Management, vol. 25 , pp. 30-48, 2014.

[8] J. F. Durgee and G. Agopian, "Refurbishing services and how services enhance consumer well-being," Journal of Services Marketing, vol. 32, no. 3, pp. 311-321, 2018.

[9] R. Desmeules, "The impact of variety on consumer happiness: marketing and the tyranny of freedom," Academy of Marketing Science Review, vol. 1, pp. 1-18, 2002.

[10] X. Sheng, J. A. Siguaw, and P. M. Simpson, "Servicescape attributes and consumer well-being," Journal of Services Marketing, vol. 30, no. 7, pp. 676-685, 2016.

[11] K. Ryu, J.-S. Han, and T. J. Lee, "Selection attributes of travel products: a case of Korean tourists to Japan," Journal of Travel \& Tourism Marketing, vol. 33, no. 5, pp. 671-686, 2016.

[12] B. J. Pine and J. H. Gilmore, "Welcome to the experience economy," Harvard Business Review, vol. 76, p. 97, 1998.

[13] B. H. Schmitt, Experiential Marketing: How to Get Customers to Sense, Feel, Think, Act, and Relate to Your Company and Brands, Free Press, New York, NY, USA, 1999.

[14] J. Hwang and S. O. Lyu, "The antecedents and consequences of well-being perception: an application of the experience economy to golf tournament tourists," Journal of Destination Marketing \& Management, vol. 4, no. 4, pp. 248-257, 2015.

[15] C. Chien and I. H. Chen, "A study of the effect of experiential marketing on customer purchase intention: case study of the taipei international sports cycle show," U.S. Sports Academy, vol. 1, pp. 1-11, 2014.

[16] F. M. Wahyuningtyas, F. Achmad, and A. Zainul, "The effect of experiential marketing on satisfaction and its impaction customer loyalty," Russian Journal of Agricultural and SocioEconomic Sciences, vol. 61, pp. 105-111, 2017.

[17] E. Devindiani and L. A. Wibowo, "Pengaruh experiential marketing terhadap customer satisfaction serta dampaknya pada customer loyalty (survei pada pengguna smartphone di komunitas online apple dan samsung regional bandung)," Journal of Business Management Education (JBME), vol. 1, no. 1, pp. 149-159, 2016.
[18] N. M. Jahromi and M. A. S. Nakhae, "Examination the interrelationships experiential marketing, experiential value, purchase behavior and their impact on customers loyalty (case study: customers of hormoz hotel in bandar-e-abbas)," Journal of Marketing And Consumer Research, vol. 12, pp. 73-87, 2015.

[19] A. C. Ahuvia and D. C. Friedman, "Income, consumption, and subjective well-being: toward a composite macromarketing model," Journal of Macromarketing, vol. 18, no. 2, pp. 153-168, 1998.

[20] K. E. Hedhli, J. C. Chebat, and M. J. Sirgy, "Shopping wellbeing at the mall: construct, antecedents, and consequence," Journal of Business Research, vol. 66, pp. 856-863, 2013.

[21] M. J. Sirgy, D.-J. Lee, S. Grzeskowiak et al., "An extension and further validation of a community-based consumer well-being measure," Journal of Macromarketing, vol. 28, no. 3, pp. 243-257, 2008.

[22] L. Van Boven and T. Gilovich, "To do or to have? that is the question," Journal of Personality and Social Psychology, vol. 85, no. 6, pp. 1193-1202, 2003.

[23] L. Nicolao, J. R. Irwin, and J. Goodman, "Happiness for sale: do experiential purchases make consumers happier than material purchases?" Journal of Consumer Research, vol. 36, no. 2, pp. 188-198, 2009.

[24] E. C. Hirschman and M. B. Holbrook, "Hedonic consumption: emerging concepts, methods and propositions," Journal of Marketing, vol. 46, no. 3, pp. 92-101, 1982.

[25] M. B. Holbrook, "The millennial consumer in the texts of our times: experience and entertainment," Journal of Macromarketing, vol. 20, no. 2, pp. 178-192, 2000.

[26] M. B. Holbrook and E. C. Hirschman, "The experiential aspects of consumption: consumer fantasies, feelings, and fun," Journal of Consumer Research, vol. 9, no. 2, pp. 132-140, 1982.

[27] M. B. Holbrook, Introduction to Consumer Value: A Frame Work for Analysis and Research, Routledge Kegan Paul Press, New York, NY, USA, 1999.

[28] C. Mathwick, N. Malhotra, and E. Rigdon, "Experiential value: conceptualization, measurement and application in the catalog and Internet shopping environment访 11 is This article is based upon the first author's doctoral dissertation completed while at georgia institute of technology," Journal of Retailing, vol. 77, no. 1, pp. 39-56, 2001.

[29] T. R. Roland and L. O. Richard, Service Quality: New Directions in Theory and Practice Newbury Park, Sage Journals, Oaks, CA, USA, 1994.

[30] J. C. Anderson, J. A. Narus, and W. Van Rossum, "Customer value propositions in business markets," Harvard Business Review, vol. 84, pp. 91-99, 2006.

[31] C. Grönroos and P. Voima, "Critical service logic: making sense of value creation and co-creation," Journal of the Academy of Marketing Science, vol. 41, no. 2, pp. 133-150, 2013.

[32] J. A. Chatman, "Matching people and organizations: selection and socialization in public accounting firms," Administrative Science Quarterly, vol. 36, no. 3, pp. 459-484, 1991.

[33] M. T. Dishaw and D. M. Strong, "Extending the technology acceptance model with task-technology fit constructs," Information \& Management, vol. 36, no. 1, pp. 9-21, 1999.

[34] C. Grönross and P. Helle, "Adopting a service logic in manufacturing," Journal of Service Management, vol. 21, pp. 676-685, 2010.

[35] R. J. Varey, "Marketing means and ends for a sustainable society: a welfare agenda for transformative change," Journal of Macromarketing, vol. 30, no. 2, pp. 112-126, 2010. 
[36] P. Hills and M. Argyle, "The oxford happiness questionnaire: a compact scale for the measurement of psychological wellbeing," Personality and Individual Differences, vol. 33, no. 7, pp. 1073-1082, 2002.

[37] P. M. Podsakoff, S. B. MacKenzie, J.-Y. Lee, and N. P. Podsakoff, "Common method biases in behavioral research: a critical review of the literature and recommended remedies," Journal of Applied Psychology, vol. 88, no. 5, pp. 879-903, 2003.

[38] J. F. Hair, W. C. Black, B. J. Babin, and R. L. Tatham, Multivariate Data Analysis, Prentice-Hall, Upper Saddle River, NJ, USA, 2009.

[39] R. M. Barron and D. A. Kenny, "The moderator-mediator variable distinction in social psychological research: conceptual, strategic, and statistical considerations," Journal of Personality and Social Psychology, vol. 51, pp. 1173-1182, 1986.

[40] K. J. Preacher and A. F. Hayes, "SPSS and SAS procedures for estimating indirect effects in simple mediation models," Behavior Research Methods, Instruments, \& Computers, vol. 36, no. 4, pp. 717-731, 2004.

[41] J. Cohen, P. Cohen, S. G. West, and L. S. Aiken, Applied Multiple Regression/Correlation Analysis for the Behavioral Sciences, Lawrence Erlbaum Associates, Mahwah, NJ, USA, 2003.

[42] A. F. Hayes, An Introduction to Mediation, Moderation, and Conditional Process Analysis: A Regression Based Approach, Guilford Press, New York, NY, USA, 2013.

[43] D. Muller, C. M. Judd, and V. Y. Yzerbyt, "When moderation is mediated and mediation is moderated," Journal of Personality and Social Psychology, vol. 89, no. 6, pp. 852-863, 2005.

[44] J. C. Sweeney and G. N. Soutar, "Consumer perceived value: the development of a multiple item scale," Journal of Retailing, vol. 77, no. 2, pp. 203-220, 2001. 